\title{
LIFE FOR THE FAMILIES OF THE VICTORIAN CRIMINALLY INSANE*
}

\section{JADE SHEPHERD}

University of Lincoln

\section{Running head: FAMILIES OF THE VICTORIAN INSANE}

Abstract. This article uses hundreds of letters written by the families of patients committed into Victorian Broadmoor Criminal Lunatic Asylum to provide the first sustained examination of the effects of asylum committal on patients' individual family members. It shows that despite what historians have previously suggested the effect on families was not solely, or even necessarily primarily, economic; it had significant emotional effects, and affected family members' sense of self and relationships outside the asylum. It also shows that family ties and affective relationships mattered a great deal to working-class Victorians. Some found new ways to give meaning to their relationship with, and the life of, their incarcerated relative, despite the costs this entailed. By taking a new approach - engaging with the history of the family, shifting focus from patients to their individual family members, and considering factors including age, class, gender, change over time and life stage - this article demonstrates the breadth and depth of the effects of asylum committal, and in doing so provides new and significant insights into the history of the Victorian asylum. It also enriches the history of the family by providing an insight into working-class quotidian lives, bonds, and emotions.

\footnotetext{
School of History and Heritage, University of Lincoln, Lincoln, LN6 7TS jshepherd@lincoln.ac.uk * I would like to thank Joel Morley for reading multiple drafts of this article, the three anonymous reviewers for their very kind and generous feedback, and Emma Griffin for her swift and helpful communication following the acceptance of this article.
} 
In the early 1890s Mrs Cooper, seemingly fraught and worn-down, replied to a letter from her husband who had been incarcerated in Broadmoor, England and Wales' first criminal lunatic asylum, for twenty-five years:

I was surprised that you will continue writing as I wish you would not as it upsets me very much and I hope you won't do so any more ... I trust you will never write to me again nor any one else as it makes me ill from all the sorrow I have gone through.

And ask God to forgive you as I have had a struggling time of it these last 25 years it has brought me down to a poor old woman and your children have quite forgot you and never think anything of you and no one never mentions your name.

And as for the children they are all scattered about the country trying to get an honest living and have nothing to share and I have nothing.

She declared she was leaving her home and 'there will be no one to take any more letters in so its no use writing. ${ }^{1}$ Only fragments of this letter remain; how she addressed her husband or ended the letter is unknown. Nevertheless, what is there is visceral, reflecting years of distress and hardship. Other documents in

\footnotetext{
${ }^{1}$ Berkshire Record Office (BRO), D/H14/D2/2/1/373/6. All references beginning D/H14 are from the BRO; all are to letters unless stated otherwise, with sender/recipient omitted if evident in the text.
} 
Cooper's case file suggest his family severed ties with him. Years later, when

Cooper was gravely ill, Broadmoor's staff wrote a note to inform his loved ones.

They failed to locate them and 'no friends' was scribbled on the note. Such cases

highlight the long-term pain and hardship some families experienced due to

having a breadwinner, father and husband committed into Broadmoor. Such

letters allow historians to view asylums from the bottom-up, providing a glimpse

at 'the human and emotional side of patient and family lives, an aspect that is

often missing from official bureaucratic sources. ${ }^{2}$ These rare, valuable sources

enable new and significant insights into the Victorian asylum.

The 1845 Asylums Act required each county in England and Wales to

have an asylum for its pauper insane. Scholars and historians of psychiatry have debated the role and significance of the Victorian asylum. Much attention has been paid to why asylums emerged, why patients were admitted and how they were treated, why patients were discharged, and the experiences of those who worked and lived inside them. ${ }^{3}$ Over the last thirty years historians have responded to Roy Porter's call to write medical history 'from below', with a focus on patients. Doing so has helped to develop our understanding of the role and

\footnotetext{
2 Louise Wannell, 'Patients' relatives and psychiatric doctors: letter writing in the York Retreat, 1875-1910', Social History of Medicine, 20 (2007), pp. 297-313 at p. 299.

3 Jonathan Andrews and Anne Digby, eds., Sex and seclusion, class and custody: perspectives on gender and class in the history of British and Irish psychiatry (New York, 2004); Joseph Melling, Bill Forsythe and Richard Adair, 'Families, communities and the legal regulation of lunacy in Victorian England: assessments of crime, violence and welfare in admissions to the Devon Asylum, 1845-1914', in Peter Bartlett and David Wright, eds., Outside the walls of the asylum: the history of care in the community 1750-2000 (London and New Brunswick, 1999), pp. 153-80; Anne Digby, Madness, morality and medicine: a study of the York Retreat 1796-1914 (Cambridge and New York, 1985); Michel Foucault, History of madness, trans. by John Murphy and Jean Khalfa (London and New York, 2006); Louise Hide, Gender and class in English asylums, 1890-1914 (Basingstoke, 2014); Andrew Scull, The most solitary of afflictions: madness and society in Britain, 1700-1900 (New Haven and London, 1993); Joseph Melling and Bill Forsythe, The politics of madness: the state, insanity and society in England, 1846-1914 (London and New York, 2006).
} 
reach of the asylum. ${ }^{4}$ Given that many families were involved in the committal of insane relatives into asylums, it stands to reason that most patients had at least one family member affected by their committal. There are swathes of the population - the spouses, children, parents and siblings of the insane, as well as their friends and neighbours - whose lives were affected by the existence of these institutions. Yet we know little about how patients' families in England and Wales were affected by, responded to, and overcame a relative's asylum committal. Work thus remains to be done if we are to understand the full impact and reach of the asylum.

While excellent studies do exist, what we know about patients' families represents the tip of the iceberg. We know that families wrote to asylums to request information or express concern about their relative's wellbeing, to ask about an asylum's procedures, or to obtain their relative's discharge. ${ }^{5}$ Yet historians' considerations of these points rarely include the broader social and familial context of such requests and concerns. Historians have acknowledged that asylum records are useful for exploring family life, but their focus tends towards the (domestic) reasons individuals developed insanity; how families coped with caring for an insane relative at home; families' roles in admission and discharge; and families' relationships with asylum doctors, and their role in

\footnotetext{
${ }^{4}$ Roy Porter, 'The patient's view: doing medical history from below', Theory and Society, 14 (1985), pp. 175-98; Allan Beveridge, 'Life in the asylum: patients' letters from Morningside, 1873-1908', History of Psychiatry, 9 (1998), pp. 431-69; Alexandra Bacopoulos-Viau and Aude Fauvel, 'The patient's turn. Roy Porter and psychiatry's tales, thirty years on', Medical History, 60 (2016), pp. 1-18; Leonard D. Smith "Your very thankful inmate": discovering the patients of an early county lunatic asylum', Social History of Medicine, 21 (2008), pp. 237-52.

${ }^{5}$ Charlotte Mackenzie, Psychiatry for the rich: a history of Ticehurst Private Asylum, 1792-1917 (London and New York, 1992); Anna Shepherd, Institutionalizing the insane in nineteenth-century England (Oxon, 2014), pp. 72-87.
} 
shaping medical care. ${ }^{6}$ When the impact on families is explicitly considered the focus tends towards the material effect upon the household. ${ }^{7}$ But focusing on economics does not go far enough. It paints Victorian families as primarily pragmatic units of domestic economics rather than the living, feeling people that historians of the family have uncovered. ${ }^{8}$ Moreover, approaches which consider the household rather than its constituents overlook the fact that effects were not contained within single households and, more importantly, that different family members were affected differently and found different ways to overcome the loss of a relative to the asylum. Overlooking these things underplays the significance and impact of the Victorian asylum, and misrepresents the Victorian working-class families trying to navigate life without a spouse, parent, child or sibling. ${ }^{9}$ Recent work on Irish asylums undertaken by Catherine Cox and Alice Mauger provides some evidence of affective familial bonds, ${ }^{10}$ and scholars

\footnotetext{
${ }^{6}$ Cara Dobbing, 'The family and insanity: the experience of the Garlands Asylum, 1862-1910' in Carol Beardmore, Cara Dobbing and Steven King, eds., Family life in Britain 1650-1910 (2019, Cham, Switzerland), pp. 135-54; Mark Finnane, 'Asylums, families and the state', History Workshop Journal, 20 (1985), pp. 134-48; Marjorie Levine-Clark, 'Dysfunctional domesticity: female insanity and family relationships among the West Riding poor in the mid-nineteenth century', Journal of Family History, 25 (2000), pp. 341-61; Smith, 'Thankful'; Wannell, 'Patients'; John Walton, 'Casting out and bringing back in Victorian England: pauper lunatics, 1840-1870', in William F. Bynum, Roy Porter and Michael Shepherd, eds., The anatomy of madness: essays in the history of psychiatry (3 vols., London, 1985-88), VII (1985), pp. 132-46; David Wright, 'The discharge of pauper lunatics from county asylums in mid-Victorian England: the case of Buckinghamshire, 1853-1872', in Joseph Melling and Bill Forsythe, eds., Insanity, institutions and society, 1800-1914: a social history of madness in comparative perspective (London and New York, 1999), pp. 93-113 at p. 94; Idem. 'Getting out of the asylum: understanding the confinement of the insane in the nineteenth-century', Social History of Medicine, 10 (1997), pp. 137-55.

${ }^{7}$ Cathy Smith, 'Living with insanity: narratives of poverty, pauperism and sickness in asylum records 1840-76', in A. Gestrich, E. Hurren and S. King, eds. Poverty and sickness in modern Europe: narratives of the sick poor, 1780-1938, (London, 2012), pp. 117-41.

${ }^{8}$ Ellen Ross, Love and toil: motherhood in outcast London 1870-1918 (Oxford, 1993); Julie-Marie Strange, Fatherhood and the British Working Class 1865-1914 (Cambridge, 2015).

${ }^{9}$ Dobbing established what proportion of the first hundred entries in Garlands' visitors book from 1900-1904 were spouses, siblings, or parents, and suggested this revealed the significance of sibling bonds. However, as it is unclear whether a distinction was made between unique and repeat visitors, the statistical basis of this observation may be unreliable. 'Family', pp. 143-4.

${ }^{10}$ Catherine Cox, Negotiating insanity in the southeast of Ireland, 1820-1900 (Manchester, 2012); Alice Mauger, The cost of insanity in nineteenth-century Ireland: public, voluntary and private asylum care (Basingstoke, 2017).
} 
working on colonial asylums have illuminated how families were affected emotionally. ${ }^{11}$ Catharine Coleborne has used families' correspondence with asylums in Australasia to examine the relationship between the colonial family and the asylum, observing that letters 'afford us a glimpse of emotional responses to managing mental breakdown' and insights 'into the lives of families'.12 Like Coleborne, I use families' correspondence to move beyond the walls of the asylum and unite the histories of the asylum and the family. I do this within the context of late-Victorian England, and with a focus on the day-to-day lives and experiences of the families of approximately 525 patients committed into Broadmoor between 1863 and 1900.

Broadmoor opened in 1863 in Berkshire. It housed Queen's pleasure patients, who had committed a crime and were found insane when tried, and insane convicts, who had been convicted of a crime and imprisoned before developing insanity in prison. ${ }^{13}$ Its patients came from all over England and Wales, ${ }^{14}$ and unlike many patients in county asylums most were a long way from their families. ${ }^{15}$ Like other Victorian asylums Broadmoor was not an

\footnotetext{
11 Catharine Coleborne, 'Families, patients and emotions: asylums for the insane in colonial Australia and New Zealand, c. 1880-1910', Social History of Medicine, 19 (2006), pp. 425-42; Idem. Madness in the family: insanity and institutions in the Australasian colonial world, 1860-1914 (Basingstoke, 2010); Mary-Ellen Kelm, 'Women, families and the Provincial Hospital for the Insane, British Columbia, 1905-1915', Journal of Family History, 19 (1994), pp. 177-93; Bronwyn Labrum, 'Looking beyond the asylum: gender and the process of committal in Auckland, 18701910', New Zealand Journal of History, 26 (1992), pp. 125-44.

12 Coleborne, 'Families', pp. 428, 434.

${ }^{13}$ For Broadmoor's patients, Jade Shepherd, "'One of the best fathers until he went out of his mind”: paternal child-murder, 1864-1900', Journal of Victorian Culture, 18 (2013), pp. 17-35; Idem. "I am not very well I feel nearly mad when I think of you": male jealousy, murder and Broadmoor in late-Victorian Britain', Social History of Medicine, 30 (2017), pp. 277-98; Idem. “I am very glad and cheered when I hear the flute": the treatment of criminal lunatics in lateVictorian Broadmoor', Medical History, 60 (2016), pp. 473-91.

14 Some came from Scotland, Ireland and the colonies.

${ }^{15}$ Some county asylum patients were far from home. Catherine Cox, Hilary Marland and Sarah York, 'Emaciated, Exhausted and Excited: The Bodies and Minds of the Irish in Nineteenth-Century Lancashire Asylums', Journal of Social History, 46, 2 (2012), 500-24
} 
impenetrable walled fortress. ${ }^{16}$ By writing and visiting families were almost ever-present within the asylum. Using hundreds of letters, which survive in patients' case files, I explore the material and emotional effects having a relative committed into Broadmoor had on individual family members. Historians have lamented the scarcity of such sources, ${ }^{17}$ and have extracted lay commentary from medical case notes and physicians' casebooks but, as Jonathan Andrews highlights, these report lay voices through the biased gaze of the physician. ${ }^{18}$ The quantity, content and context of the Broadmoor letters make them an unusually rich and unmediated source for examining the impacts of asylum committal on families. We can read their emotions and see glimpses of their day-to-day lives and actions. Queen's Pleasure patients' families seemingly wrote the most letters and are thus the main focus, but insane convict patients' families occasionally feature. ${ }^{19}$ While fewer letters from the latter appear to exist this does not mean they were uncaring. Some convicts were transferred to Broadmoor without their families' knowledge; some did not have the same familial networks as Queen's pleasure patients; and such networks - and/or the inclination to write letters may have been diminished by constraints on letter writing while in prison, which 'greatly reduced [letters] usefulness to anyone genuinely seeking to keep alive emotional attachment to someone outside'. ${ }^{20}$ The surviving letters reveal the practical significance of family members' relationships with their incarcerated relatives and the effects on families, both during a relative's committal and after

\footnotetext{
16 Essays in Bartlett and Wright, eds., Outside; Coleborne, Madness; Idem. 'Families'.

17 Dobbing, 'Family'.

18 Jonathan Andrews, 'Case notes, case histories, and the patient's experience of insanity at Gartnavel Royal Asylum, Glasgow, in the nineteenth century', Social History of Medicine, 11 (1998), pp. 255-81.

${ }^{19}$ More Queen's pleasure patients' case files contained letters from family members and in greater quantities than insane convicts' files.

${ }^{20}$ Philip Priestley, Victorian prison lives (London, 1999), p. 198.
} 
their discharge. Because 84 per cent of those committed into Broadmoor between 1863 and 1900 were working class, the letters also provide an unusual window into working-class family life, emotions, and subjectivities. ${ }^{21}$ In normal circumstances working-class families did not typically exchange (or keep) regular letters, ${ }^{22}$ but the enforced separation of committal encouraged epistolary correspondence, and the oral quality of the letters suggests the poor were typically writing for themselves. ${ }^{23}$ Both male and female family members, sometimes from within the same family, wrote to Broadmoor. Letters often appear to act as substitutes for conversations that we can imagine would have taken place in the home or in the superintendent's office had distance not necessitated written communication. Access to the original correspondence is, nevertheless, partial; why particular letters were kept or duplicated is indeterminable but often only one side of the conversation remains, only portions of some letters were retained, and occasionally legibility is an issue. ${ }^{24}$ Nevertheless, they are a highly valuable qualitative source. The presence of patients' replies to family members' letters shows that some reached their intended recipients. Whether or not the superintendent censored letters either by not passing them on or reading them to patients, they do show what family members wanted to communicate. They are ideal for exploring questions of

\footnotetext{
${ }^{21}$ Jade Shepherd, 'Victorian madmen: Broadmoor, masculinity and the experiences of the criminally insane, 1863-1900' (unpublished PhD thesis, Queen Mary University of London, 2013), pp. 59-62.

22 Steven King, Writing the lives the English poor 1750s-1830s (Canada, 2019), p. 20; Penny Summerfield, Histories of the self. Personal narratives and historical practice (London, 2019), p. 23.

23 In this respect they resemble the pauper letters that King and Lindsey Earner-Byrne examined. King, Writing, pp. 35-37; Earner-Byrne, "Dear father my health has broken down": writing health in Irish charity letters, 1922-1940', Social History of Medicine, 28 (2015), pp. 849-68 at p. 852.

${ }^{24}$ As the asylum did not retain all letters quantitative analysis has limited utility.
} 
family ties, agency and emotion. ${ }^{25}$ Letters between family members and to

Broadmoor's superintendent provide an intimate insight into families' emotional worlds in nineteenth-century England. They display life, emotions and relationships as they were lived in real time, rather than as they were reimagined in the composed autobiographical accounts historians tend to rely upon to examine family life and subjectivities. ${ }^{26}$

This article offers the first sustained examination of the effects of asylum committal on patients' individual family members. By shifting focus from the effects on patients to the effects on families, and by taking a new approach engaging with the history of the family, and focusing on individual family members, considering factors including age, class, gender, change over time and stage in life cycle - this article examines the reach and significance of the asylum further beyond its walls. It tells an important, untold narrative from the perspective of family members and opens new insights into the histories of the asylum and family life in the late nineteenth century. In the first half of the article it is shown that effects of asylum committal on families were not solely or even primarily economic. It affected their relationships outside of the asylum, and their sense of self; one's role in the family 'played an important part in the ... formulation of personal identity',27 and the loss of a relative to Broadmoor forced some family members to reconfigure their role. Nevertheless, despite the

\footnotetext{
25 Summerfield, Histories, p. 28.

${ }^{26}$ Joanne Bailey (Begiato), 'Masculinity and fatherhood in England c.1760-1830', in John H. Arnold and Sean Brady, eds., What is masculinity? historical dynamics from antiquity to the contemporary world (New York, 2011), pp. 167-86; Idem. Parenting in England, 1760-1830: emotion, identity, and generation (Oxford, 2012); Megan Doolittle, 'Fatherhood and family shame: masculinity, welfare and the workhouse in late nineteenth-century England', in Lucy Delap, Ben Griffin and Abigail Wills, eds., The politics of domestic authority in Britain since 1800 (Basingstoke, 2009), pp. 84-108; Emma Griffin, 'The emotions of motherhood: love, culture and poverty in Victorian Britain', American Historical Review, 123 (2018), pp. 60-85.

27 Bailey (Begiato), Parenting, p. 143.
} 
material and emotional hardships some family members faced and the challenges posed to their day-to-lives and identities, the second half of the article shows that family ties and affective relationships mattered a great deal to working-class Victorians. Some found new ways to give meaning to their relationship with their incarcerated relative despite the distance between them, and they sought to give meaning - via their words and actions - to their relative's life despite the hardships their committal into Broadmoor had caused. Yet this continued attachment had further costs for families. Where familial solidarity persisted the asylum had long-lasting and far-reaching effects, including being policed by the asylum as long as their relative lived, even if they were discharged.

II.

Committal into Broadmoor often resulted in long distance, long-term separation between families and their incarcerated relatives. Between 1863 and 1900 just 9 per cent of male patients and 25 per cent of female patients were released from the asylum. 40 per cent of male and 36 per cent of female patients died there, and 38 per cent of male patients and 30 per cent of female patients were transferred to their local county asylum ${ }^{28}$ How many were later released from their local asylum is unknown. The immediate effects of losing a relative to Broadmoor were burdensome, but the long-term impacts were often devastating. The effects were contingent upon, and evolved over, the course of the life cycle. Some family members overcame the difficulties they faced, but others did not, and here we see the influence gender, class, age, and relationship

\footnotetext{
${ }^{28}$ Shepherd, 'Victorian Madmen', p. 123.
} 
with their incarcerated relative and others had on individuals' ability to

withstand having a relative institutionalised far from home.

Most patients entered Broadmoor during the prime of their lives, between their mid-twenties and early-forties when the entire family was dependent on men's earnings, and women's domestic work, including childcare [Tables 1 and 2]. ${ }^{29}$ Many families thus found the absence of a spouse, parent, or child both financially and emotionally difficult.

\begin{tabular}{|c|c|c|c|c|c|c|c|c|}
\hline Ages & $\begin{array}{l}1864- \\
1867\end{array}$ & $\begin{array}{l}1868- \\
1872\end{array}$ & $\begin{array}{l}1873- \\
1877\end{array}$ & $\begin{array}{l}1878- \\
1882\end{array}$ & $\begin{array}{l}1883- \\
1887\end{array}$ & $\begin{array}{l}1888- \\
1892\end{array}$ & $\begin{array}{l}1893- \\
1897\end{array}$ & $\begin{array}{l}1898- \\
1900\end{array}$ \\
\hline Under 18 & 0.9 & 0.9 & 1.2 & 0.0 & 0.5 & 0.8 & 1.6 & 1.3 \\
\hline $18-27$ & 16.8 & 27.5 & 21.5 & 18.8 & 20.7 & 15.5 & 17.5 & 17.5 \\
\hline $28-37$ & 29.0 & 33.5 & 39.9 & 39.3 & 32.4 & 29.2 & 35.0 & 33.8 \\
\hline $38-47$ & 22.0 & 22.7 & 25.2 & 19.4 & 18.6 & 29.9 & 26.8 & 21.3 \\
\hline $48-57$ & 15.4 & 10.9 & 6.7 & 14.1 & 17.0 & 17.4 & 10.9 & 10.0 \\
\hline $58-67$ & 6.8 & 3.9 & 3.7 & 7.3 & 8.0 & 5.3 & 6.6 & 12.5 \\
\hline $68-77$ & 1.9 & 0.3 & 1.8 & 1.0 & 2.7 & 1.1 & 1.6 & 3.8 \\
\hline $78-87$ & 0.2 & 0.0 & 0.0 & 0.0 & 0.0 & 0.8 & 0.0 & 0.0 \\
\hline Unknown & 7.0 & 0.3 & 0.0 & 0.0 & 0.0 & 0.0 & 0.0 & 0.0 \\
\hline
\end{tabular}

Table 1. The ages of men committed into Broadmoor as a percentage of the population.

\begin{tabular}{|l|r|r|r|r|r|r|r|r|}
\hline & \multicolumn{1}{l|}{$\begin{array}{l}1863- \\
\text { Ages }\end{array}$} & \multicolumn{1}{l}{$\begin{array}{l}1868- \\
1867\end{array}$} & \multicolumn{1}{l}{$\begin{array}{l}1873- \\
1877\end{array}$} & $\begin{array}{l}1878- \\
1882\end{array}$ & $\begin{array}{l}1883- \\
1887\end{array}$ & \multicolumn{1}{l}{$\begin{array}{l}188- \\
1892\end{array}$} & $\begin{array}{l}1893- \\
1897\end{array}$ & \multicolumn{1}{l}{$\begin{array}{l}1898- \\
1900\end{array}$} \\
\hline Under 18 & 0.0 & 0.0 & 0.0 & 1.3 & 0.0 & 0.0 & 1.5 & 0.0 \\
\hline $18-27$ & 27.0 & 25.0 & 25.5 & 21.1 & 26.8 & 15.6 & 24.6 & 25.0 \\
\hline $28-37$ & 29.1 & 37.5 & 34.5 & 35.5 & 35.2 & 34.4 & 38.5 & 20.8 \\
\hline $38-47$ & 25.0 & 27.8 & 34.5 & 31.6 & 29.6 & 34.4 & 21.5 & 29.2 \\
\hline $48-57$ & 8.8 & 6.9 & 5.5 & 7.9 & 5.6 & 10.9 & 10.8 & 12.5 \\
\hline $58-67$ & 2.7 & 1.4 & 0.0 & 2.6 & 2.8 & 3.1 & 3.1 & 8.3 \\
\hline $68-77$ & 0.0 & 0.0 & 0.0 & 0.0 & 0.0 & 0.0 & 0.0 & 4.2 \\
\hline $78-87$ & 0.0 & 0.0 & 0.0 & 0.0 & 0.0 & 0.0 & 0.0 & 0.0 \\
\hline Unknown & 7.4 & 1.4 & 0.0 & 0.0 & 0.0 & 1.6 & 0.0 & 0.0 \\
\hline
\end{tabular}

Table 2. The ages of women committed into Broadmoor as a percentage of Broadmoor's female population. 
Both husbands and wives were thrust into the dual role of homemaker and provider and each struggled. Family historians have shown how instrumental women were to the Victorian home; they were wage earners, homemakers and carers. ${ }^{30}$ Yet female patients' families rarely sought to retrieve money. One family sought money for their relative's young daughter but perhaps only because the child's father was absent. ${ }^{31}$ It is unsurprising, given how central managing the home and caring for children was to working-class wives, that the loss of a homemaker and mother concerned families. One patient's mother asked the superintendent: 'do you think she will ever be able to manage her family anymore?’32 Many 'distressed' husbands told Broadmoor's superintendent they were 'very anxious' to have their wives 'home again'.33 Some worried that their wives were not seeing their children enough. Bridget Hart's husband could not afford to take his five children to Broadmoor and asked the superintendent whether she could be transferred to their local asylum so 'that she could see her children often'.34 But husbands also missed their companion. Their letters make their love and attachment clear; Annie Ingham's husband longed to maintain correspondence with his wife. ${ }^{35}$ That the loss of female relatives was felt in such ways demonstrates the strength of affective bonds. While their income would not always stretch to cover the return train fare to Broadmoor, patients' husbands were not ordinarily thrust into poverty as a result of their wife's committal. In his study of Victorian suicide Victor Bailey argues that the loss of a

\footnotetext{
${ }^{30}$ Ellen Ross, Love; Elizabeth Roberts, $A$ woman's place: an oral history of working-class women 1890-1940 (Oxford, 1984), p. 136; Jane Lewis, 'The working-class mother and state intervention, 1870-1918', in Jane Lewis, ed., Labour and love: women's experience of home and family (New York: 1986), pp. 99-120 at p. 107.

$31 \mathrm{D} / \mathrm{H} 14 / \mathrm{D} 2 / 2 / 2 / 175 / 53$, to superintendent.

$32 \mathrm{D} / \mathrm{H} 14 / \mathrm{D} 2 / 2 / 2 / 178 / 5$.

${ }_{33}^{3}$ D/H14/D2/2/2/183/7; D/H14/D2/2/2/164/7; D/H14/D2/2/2/398/14.

${ }^{34} \mathrm{D} / \mathrm{H} 14 / \mathrm{D} 2 / 2 / 2 / 184 / 6$.

${ }^{35} \mathrm{D} / \mathrm{H} 14 / \mathrm{D} 2 / 2 / 2 / 183 / 4$, to superintendent.
} 
spouse disrupted men's domestic lives more than women's. ${ }^{36}$ An absent wife was challenging for husbands, and certainly caused emotional distress, but although some moved away to work, sometimes abroad, ${ }^{37}$ and others started new families, ${ }^{38}$ husbands were seemingly more willing and (financially) able to preserve their home than patients' wives. Their ability to remain a breadwinner, particularly by relying upon their sisters or sisters-in-law to help care for their children, meant they had less need to reformulate their own role in the family, or the family structure, than patients wives, who correspondence suggests suffered more.

In the late nineteenth century being a husband and father meant leading and exerting authority over the household, and providing financially. Their husbands' absence forced some patients' wives to reformulate their identities by assuming these responsibilities. In some ordinary working-class households 'mothers made a point of their husbands' authority'; fathers were 'judge and arbiters of rewards and punishments. ${ }^{39}$ Patients' wives could hardly threaten 'you wait till your father gets home', but some did request their incarcerated husbands perform an aspect of their paternal duty by exerting authority and influence over their (older and generally male) children. Joseph Redding's wife wrote to him regarding their son:

I can assure you he has been a very great deal of trouble ever since he was 15 years old ... if only he would keep from hateful drink ... I think you had

\footnotetext{
36 Bailey, Rash, pp. 234-235.

37 D/H14/D2/2/2/183.

$38 \mathrm{D} / \mathrm{H} 14 / \mathrm{D} 2 / 2 / 2 / 101$.

${ }^{39}$ Helen Rogers, "First in the house": daughters on working-class fathers and fatherhood' in Trev Broughton and Helen Rogers, eds., Gender and fatherhood in the nineteenth century (Basingstoke, 2007), pp. $126-37$ at p. 128.
} 
better write to him perhaps it will do him good for we are all very

frightened of him..$^{40}$

In conjunction with recent studies on fatherhood, such correspondence indicates

that working-class fathers were understood to be more than providers, their loss felt in non-material ways. ${ }^{41}$

Nevertheless, money was a concern. What many wives needed from their husbands was money to support themselves and their children. ${ }^{42}$ Some survived without their husband's wages or physical presence. One continued her husband's rope-making business, and others claimed their pensions or savings. ${ }^{43}$ But such cases were rare because most male patients did not have these things. Financial survival was easier for wives with few or no dependent children, or with older children who could contribute to the household economy. ${ }^{44}$ But most wives were left to care and provide for their young children alone, with devastating consequences. Low wages and seasonal work disproportionately affected women, so even if women were in or found work their earnings would not have matched their husbands, ${ }^{45}$ and employment would not necessarily have significantly reduced their anxieties: they still had homes to maintain and children to care for. The limited agency working-class wives possessed, and in

\footnotetext{
${ }^{40} \mathrm{D} / \mathrm{H} 14 / \mathrm{D} 2 / 2 / 1 / 1102 / 71$.

${ }^{41}$ Essays in Broughton and Rogers, eds., Gender; Eleanor Gordon and Gwyneth Nair, 'Domestic fathers and the Victorian parental role', Women's History Review, 15 (2006), pp. 551-9; Vicky Holmes, In bed with the Victorians: the life-cycle of working-class marriage (Basingstoke, 2017), p. 104; Julie-Marie Strange, 'Fatherhood, providing and attachment in late-Victorian and Edwardian working-class families', Historical Journal, 55 (2012), pp. 1007-27.

42 Ross, Love; Strange, Fatherhood, p. 51.

${ }_{43}$ D/H14/D2/2/1/905/18; D/H14/D2/2/1/887/5-17; D/H14/D2/2/1/811.

${ }^{44}$ Anna Davin, Growing up poor: home, school and street in London, 1870-1914 (London, 1996).

${ }^{45}$ Carl Chinn, They worked all their lives: women of the urban poor in England, 1880-1939

(Manchester, 1988), pp. 86-8.
} 
particular their inability to live independently of their husbands, ${ }^{46}$ meant the loss of a husband was in many ways more traumatic than the loss of a wife.

Numerous 'anxious' and 'desolate' wives begged the superintendent for their husband's release because they feared starvation and poverty, as also happened following the death or prolonged un- or underemployment of a breadwinner. ${ }^{47}$ To survive, some sought poor relief or took in lodgers. ${ }^{48}$ Others had little choice but to dismantle their homes. Some considered selling their belongings, but others remarried or co-habited. ${ }^{49}$ Patient Arthur Ludlow's wife had an illegitimate child, and his sister informed him '[your wife] considers she is utterly free from you and tends doing the best for herself and children. ${ }^{50}$ Some wives made hard decisions. Unable to support all of their children, Robert Jones' wife sent their ten-year-old daughter to a home for Waifs and Strays because it was deemed 'best for [the] child as she will have training as well as [the] comforts of a good home' which her mother could not provide. ${ }^{51}$ Patient Joseph Mallon's wife was 'very anxious' about her husband who 'was always good and dutiful to me being a provider to 3 helpless children'.52 After the superintendent explained that her husband's release was not imminent, Mallon's wife told him that the 'one shilling and six pence and one loaf of bread' her local parish gave her was inadequate. She asked whether Broadmoor had a school for patients'

\footnotetext{
46 Nineteenth-century society 'assumed female dependency' to be the norm. Lewis, 'workingclass wife', p. 106.

${ }_{47}$ D/H14/D2/2/1/799/4 and 11; D/H14/D2/2/1/1689; D/H14/D2/2/1/1085/26;

D/H14/D2/2/1/599/4. Joanna Bourke, Working-class cultures in Britain 1890-1960 (London, 1994), pp. 71-81; Julie-Marie Strange, Death, grief and poverty in Britain, 1870-1914 (Cambridge, 2005), p. 194; Strange, Fatherhood, p. 56.

48 D/H14/D2/2/1/830/8, to superintendent; D/H14/D2/2/1/1102/33. Women often used

lodgers to supplement their income, Roberts, Woman's, p. 141.

${ }^{49}$ For example, D/H14/D2/2/1/829; D/H14/D2/2/1/900/9.

${ }^{50} \mathrm{D} / \mathrm{H} 14 / \mathrm{D} 2 / 2 / 1310$.

${ }^{51} \mathrm{D} / \mathrm{H} 14 / \mathrm{D} 2 / 2 / 1 / 1680$, to superintendent.

${ }^{52} \mathrm{D} / \mathrm{H} 14 / \mathrm{D} 2 / 2 / 1 / 599 / 4$, to superintendent.
} 
children because 'I am not able to support them ... I think they would be better in a school I was told there was a school now open for them.' He replied that there was 'no such school'; what happened to the children is unknown. ${ }^{53}$ Mallon's wife was likely thinking of schools for convicts' children. ${ }^{54}$ Other patients' wives sent their children to such schools and because they were gendered this sometimes meant separating siblings. ${ }^{55}$ These cases suggest that unlike some patients' husbands, and unlike was the case in some areas, not all women had access to familial or community support networks within which 'auxiliary parents' relatives and neighbours - operated. ${ }^{56}$ To avoid the workhouse they had to choose; they could not be both breadwinner and homemaker. Some families relocated which explains the lack of kinship. The stigma of having a criminal lunatic for a relative - and the shame attached to both criminality and insanity might have led to some families being shunned by their communities or discouraged them from asking for help. Unlike ordinary asylum patients who were sometimes secretly admitted by their families, ${ }^{57}$ Queen's pleasure patients were rarely sent to Broadmoor without their neighbours' knowledge; press coverage of their crime and trial, or being called to the witness stand, made sure of that.

\footnotetext{
${ }^{53} \mathrm{D} / \mathrm{H} 14 / \mathrm{D} 2 / 2 / 1 / 599 / 6$. The Poor Law Guardians recognised that this alone, the maximum most received, was barely enough to keep families from the workhouse. Ginger Frost, Victorian childhoods (London, 2009), p. 124.

${ }^{54}$ From 1866 onwards 'destitute children of a serving prisoner' could be admitted into industrial schools. Barry Godfrey, Pamela Cox, Heather Shore and Zoe Alker, Young criminal lives: life courses and life chances from 1850 (Oxford, 2017), p. 30. ${ }^{55} \mathrm{D} / \mathrm{H} 14 / \mathrm{D} 2 / 2 / 1936 \mathrm{a}$.

${ }^{56}$ Ross, Love, p. 156. People who struggled expected family members to help, King, Writing, pp. 75-81.

${ }^{57}$ Some families requested privacy when committing relatives into asylums. Akihito Suzuki, Madness at home: the psychiatrist, the patient and the family in England, 1820-1860 (California, 2006), p. 121.
} 
Patients' parents were both grief-stricken and threatened by the loss of a male wage earner. Whilst they might have initially managed financially, longterm detention was more likely to have noticeable material effects on their lives. Financing old age was a pressing concern for the aging working class, for whom reduced employment opportunities ensured the spectre of the workhouse loomed large. ${ }^{58}$ Without state pensions, many depended upon their wageearning children. ${ }^{59}$ One patient's father told Broadmoor's superintendent: 'I am ... getting old and if I could only obtain his liberty he would be of great assistance to me.'60 However, and despite the material hardships some feared, while some patients' spouses had little choice but to reframe their role in the family, patients' parents might have achieved a renewed sense of purpose. In ordinary life, some aging men and women struggled with their loss of parental identity as their children became independent. ${ }^{61}$ Efforts to assist their now-dependent adult child may have provided patients' parents the opportunity to continue (or resume) their parental role. Some tried to influence their child's experience at Broadmoor, to provide reassurance, and promised to care for them if released. ${ }^{62}$ Patient Mary Dyson's father told her that her husband had started a new family, and in a powerful statement of attachment he reminded her that she was not alone: 'You have a good mother and a good father ... you have four brothers and

\footnotetext{
${ }^{58}$ Akihito Suzuki, 'Lunacy and labouring men: narratives of male vulnerability in mid-Victorian London', in Roberta Bivins and John V. Pickstone, eds., Medicine, madness and social history, essays in honour of Roy Porter (Basingstoke, 2007), pp. 118-28.

${ }_{59}$ Pat Thane, Old age in English history: past experience, present issues (Oxford, 2000), p. 297. ${ }^{60} \mathrm{D} / \mathrm{H} 14 / \mathrm{D} 2 / 2 / 1 / 1092 / 15$. Also, D/H14/D2/2/1/900/5. The expectation that children might help aging parents is also evident in cases where patients' adult children offered their homes to them. D/H14/D2/2/1/1085/21 and 23-28, to superintendent. Elderly men found themselves unemployed and in the workhouse sooner than women. Davin, Growing, p. 25.

${ }^{61}$ Bailey, Rash, p. 211.

${ }^{62}$ D/H14/D2/2/1/900/4, to patient Ball; D/H14/D2/2/1/900/5, to superintendent. Many parents were in almost constant contact with the superintendent. D/H14/D2/2/1/1068/22-56; D/H14/D2/2/1/901/5-25.
} 
two sisters'. He reassured his 'Dear Daughter', 'if you get your liberty myself and your brother has a home and a good one for you as long as we live'.63 Fathers of sons demonstrated their attachment in traditional ways, promising to provide work or vocational instruction upon release, much as they might have done when they were on the cusp of adulthood. ${ }^{64}$ Of course, meeting the needs of grown children infantilized by insanity may have been an additional stress for parents facing the 'myriad losses' of old age - earnings, physical ability, and their spouse. 65

Establishing how patients' young children felt about losing a parent to the asylum is difficult. ${ }^{66}$ Young children's guardians often communicated messages from them to their incarcerated relative: 'goodnight kisses' and wishes, and a Happy Christmas and New Year. ${ }^{67}$ The difficulty of cajoling young children into verbalising messages might have encouraged the author to embellish with the aim of improving a relative's morale. Certainly, some young children did not appear to understand what had happened, or the importance of their well wishes or news of their wellbeing to their detained parent. Mary Ann Daniels' young daughter was being cared for by her mother who sent Daniels a photograph (a 'likeness') of her. Whether in addition to visiting, or to compensate for an inability to do so, the provision of this keepsake can be read as an act of care, intended to comfort and reassure, yet the child's energy caused a need for

\footnotetext{
${ }^{63} \mathrm{D} / \mathrm{H} 14 / \mathrm{D} 2 / 2 / 2 / 101 / 12$.

${ }^{64} \mathrm{D} / \mathrm{H} 14 / \mathrm{D} 2 / 2 / 1 / 974 / 3$, to superintendent; Claudia Nelson, Family ties in Victorian England (London, 2007), p. 91.

65 Bailey, Rash, p. 212.

66 To access Victorian children's experiences historians have used trial transcripts, official documents, autobiographies, fiction and, when possible, letters. Essays in Jane Eva Baxter and Meredith A. B. Ellis, eds., Nineteenth century childhoods in interdisciplinary perspective (Oxford, 2018).

${ }^{67} \mathrm{D} / \mathrm{H} 14 / \mathrm{D} 2 / 2 / 2 / 184 / 9$, to superintendent; D/H14/D2/2/1/1076/11, to George Varschagen; D/H14/D2/2/1/ 925/7, Christmas card.
} 
written reassurance: 'you must not think anything about that black that is upon one of her eyes because she wood not sit still ... we could not get her to sit still.'68 Older children were more conscious of a parent's absence, especially at particular points in the year including Christmas and birthdays. ${ }^{69}$

We can assume that for some having a parent detained at Broadmoor was devastating and confusing, shaking any semblance of stability or normality. For some this began the moment their parent committed a crime; some lost a sibling or parent; some testified at their parent's trial. ${ }^{70} \mathrm{~A}$ parent's committal into Broadmoor disrupted a child's home life; not only was (at least) one parent absent, but stepparents, stepsiblings, or half-siblings sometimes appeared. Some children were sent away from home, or affected by the poverty and starvation feared or felt within their home. This also had emotional consequences. In her study of Victorian working-class autobiographies, Julie-Marie Strange observed that 'some children were undoubtedly contemptuous in adulthood of fathers who had not done enough to support families. ${ }^{71}$ This appears in the Broadmoor correspondence, too. As they aged, and perhaps having had time to reflect upon their childhood, some older children criticized their father for leaving their mother destitute. Many years after he was confined, Dodwell sent numerous letters home accusing his wife of infidelity. ${ }^{72}$ Like other Victorian children who retrospectively viewed their poor and hard-working mothers as 'self-sacrificing'

68 D/H14/D2/2/2/175/22. Grandparents had a long history of providing 'substitute parenting'. Bailey (Begiato), Parenting, p. 204.

${ }^{69}$ D/H14/D2/2/1/936a/204; D/H14/D2/2/1/936b/28.

70 Shepherd, 'Best'.

${ }^{71}$ Strange, Fatherhood, p. 80.

${ }^{72}$ D/H14/D2/2/1/936c. 
and 'heroic', his eldest son, Henry, defended his mother and whilst doing so highlighted Dodwell's failure as a father to provide: ${ }^{73}$

mother has behaved in a way that would be a model to another woman left with a family of four young children, owing the last 16 years of her life has been one of anxiety and misery, and times scarcely not knowing where the next meal was to come. ${ }^{74}$

Some child-parent relationships were maintained through correspondence, evolving as children aged. As also occurred in ordinary circumstances, when children became less reliant upon parents for provision they instead sought advice. ${ }^{75}$ Sons in particular detailed their daily struggles to their fathers, perhaps hoping to receive some guidance. ${ }^{76}$ Other sons rejected their father's attempts to guide them. Dodwell wrote to Henry at work, relating his grievances and advising him to change employment. Henry responded: 'I think I told you once before that there were no letters allowed in the stores, but within this last week I have received two notes, which I thank you for nearly getting me discharged'. He continued, 'I don't wish to receive any more worrying letters ... neither am I going to be talked over by anyone to do what I do not wish to do' ${ }^{77}$ Such attempts to deny fathers the opportunity to fulfill their paternal role were not necessarily the result of hard feelings caused by their incarceration, but mirror tensions between ordinary Victorian fathers and their sons. ${ }^{78}$

\footnotetext{
73 Davin, Growing, p. 26; Griffin, 'Emotions'.

74 D/H14/D2/2/1/936c/104, to Dodwell.

75 Strange, Fatherhood, p. 41.

${ }^{76} \mathrm{D} / \mathrm{H} 14 / \mathrm{D} 2 / 2 / 1 / 765 / 23$.

${ }^{77} \mathrm{D} / \mathrm{H} 14 / \mathrm{D} 2 / 2 / 1 / 936 \mathrm{~b} / 166$.

78 Nelson, Family, p. 93.
} 
Some families were determined to protect children from the trauma of visiting or hearing from their relative, but this could result in family tension. Patient Annie Ingham's seven-year-old son was told she had died, discovering the truth ten-years later. ${ }^{79}$ We can only imagine the subsequent tension between him and his father who had kept the secret. In other cases, the tension caused by efforts to protect children is explicit. By their own accounts, Dodwell's children missed him terribly when they were young, but Dodwell's daughter later confessed to her father that their mother had encouraged them not to write, ${ }^{80}$ and their mother asked the superintendent to send letters intended for the children to her because 'they prove to be of disadvantage to the young people.'81 Dodwell's case is unusual because it was assumed that his children were better off without him. The chaplain and master at Emmanuel Hospital explained his concerns to Broadmoor's superintendent, echoing the message of Religious Tract Society stories in which absent or inadequate fathers needed replacing with an appropriate male role model: ${ }^{82}$

I have done my best to benefit his children ... I fear that if he were set free, it could be of little good to his children. He would remove his eldest boy from here where he is getting a useful education, good food and every possible care, and his other children from their place of shelter.

He expressed his fears clearly: 'I think the first thing is to protect this poor family from the ... utter [devastation] that would ensue if the father were set free.' 83 The

\footnotetext{
${ }^{79} \mathrm{D} / \mathrm{H} 14 / \mathrm{D} 2 / 2 / 2 / 183 / 33$, to superintendent.

$80 \mathrm{D} / \mathrm{H} 14 / \mathrm{D} 2 / 2 / 1 / 936 \mathrm{~b} / 28$.

$81 \mathrm{D} / \mathrm{H} 14 / \mathrm{D} 2 / 2 / 1 / 936 \mathrm{~b} / 195$.

82 Stephanie Olsen, 'The authority of motherhood in question: fatherhood and the moral education of children in England, c. 1870-1900', Women's History Review, 18 (2009), pp. 765-80 at p. 772.

${ }^{83} \mathrm{D} / \mathrm{H} 14 / \mathrm{D} 2 / 2 / 1 / 936 \mathrm{a} / 209-10$.
} 
confusion and distress that resulted from having an incarcerated parent, and the subsequent efforts of family and friends to protect children, appeared to inspire within some children (who were coming of age and perhaps longing to exercise some independence) a desire to demonstrate their filial duty, a notion grounded in scripture: the honouring of one's mother and father. Unlike some patients' spouses who reconfigured their identities or assumed new roles in order to survive, patients' young children retained their identities as dutiful children. Dodwell's youngest son, Edward, ran away from school to visit his father, perhaps influenced by his father's numerous letters demanding he and his siblings remain 'faithful' to him. ${ }^{84}$ As some children aged an evolution in the child-parent relationship is evident in their correspondence (or lack of). Edward stopped writing to and visiting his father, but his brother, Henry, despite the angry letters he had previously sent to his father, continued to correspond with him and Broadmoor's superintendents. As he aged, Henry indulged his father's quirks and demands, expressing compassion and pity for a father he came to perceive as 'fragile' rather than failing. ${ }^{85}$ It is clear that having a parent at Broadmoor, a situation akin to having a neglectful or absent father, did not always strain parent-child relationships beyond repair. Anthony Owston's sons were very young when he murdered their mother and was sent to Broadmoor, but they remained a constant and supportive presence in his life until his death. ${ }^{86}$ This research supports what Strange found in her examination of autobiographies: 'when providing faltered, father-child dynamics might come under strain but, in long view, could survive and become manifest in alternative

\footnotetext{
${ }^{84}$ He visited him thirty-five times in February 1885. D/H14/D2/2/1/936b/67, memorandum; for example, D/H14/D2/2/1/936b/47, letter to 'undutiful' daughter. ${ }^{85}$ Strange develops the idea of a 'fragile' father in Fatherhood, pp. 49-81. ${ }^{86} \mathrm{D} / \mathrm{H} 14 / \mathrm{D} 2 / 2 / 1 / 963$.
} 
ways.' ${ }^{87}$ Moreover, that correspondence allows us to see this in real time confirms that this is not an effect of rose-tinted autobiographical writing, but evidence of resilient parent-child bonds.

Having a relative committed into Broadmoor had effects that spread far beyond the asylum walls and into the wider family and community. During the nineteenth century some poor families lived in close proximity to one another and provided mutual support. ${ }^{88}$ This helped to relieve the burden on some families who, without access to formal or charitable support networks for the families of the insane, united to support and protect each other financially and emotionally. Efforts to protect those directly affected drew others into correspondence with the asylum. One patient's brother begged the superintendent to release his sister because he was concerned about their 'disparing' mother, ${ }^{89}$ and a friend of a patient's wife - aware that she was 'sometimes subject to violent hysterical fits' - asked the superintendent to prevent 'the poor woman much misery' by dissuading her from visiting Broadmoor. ${ }^{90}$ Some family members tried to survive and move forward in their own way: the father who told his son his mother was dead; the mother who tried to stop her children from communicating with their father; the spouses who remarried; the worried daughter-in-law who secretly begged the superintendent to reject her husband's petition for the release of his father. ${ }^{91}$ But each of these methods of survival potentially carried further damaging consequences: tension,

\footnotetext{
87 Strange, Fatherhood, p. 81.

88 Thane, Old age, p. 299; D. Cooper and M. Donald, 'Households and "hidden" kin in earlynineteenth century England': four case studies in suburban Exeter, 1821-1861', Continuity and Change, 10 (1995), pp. 257-78.

${ }^{89} \mathrm{D} / \mathrm{H} 14 / \mathrm{D} 2 / 2 / 2 / 175 / 48$.

${ }^{90} \mathrm{D} / \mathrm{H} 14 / \mathrm{D} 2 / 2 / 1 / 918 / 16$.

$91 \mathrm{D} / \mathrm{H} 14 / \mathrm{D} 2 / 2 / 1 / 1076 / 18$.
} 
conflict and secrecy within the home. Correspondence reveals struggles between family members that might not have ordinarily existed. Patient Charles Cornish's wife was admonished by her 'pig-headed old mother-in-law' who 'reproaches her with neglect' because she was reluctant to visit her husband..$^{92}$ Such cases were not unusual, ${ }^{93}$ and patients became the subject of tension between marital and blood relations which, in normal circumstances, they might have mediated.

The preceding discussion shows losing a wage earner or home maker had significant effects on the family, not only potentially causing poverty but also the temporary or permanent reconfiguration of the family, reliance upon kinship networks to maintain the family's health and integrity, and shaping familial relationships. Importantly, it demonstrates that who entered the asylum mattered: the effects on and concerns of family members depended on their relationship with the patient. For spouses, gender and class affected the significance of the impacts, but an individual's life stage and ability to access support networks were also important. Unsurprisingly, those with limited agency felt the impacts of losing a relative to Broadmoor the most. Some wives and parents not only felt effects immediately, but also forfeited their imagined financially secure future because that expectation was premised upon provision by their spouse or child. Wives also faced the greatest challenge to their sense of self, particularly if they had to dismantle their home, allow others to care for their children, or assume an unexpected role. This may explain why marriage appears to have been the most fragile bond, while blood kinship proved more resilient. Examining tangible, structural effects on patients' families also reveals 
the emotional impacts. While family members responses were complex and often contradictory, changing over time and in relation to their own life stage, they suggest the importance and resilience of familial ties. Cutting across the differences in experience is the way that family members expressed their loss: they were 'bereaved', 'heartbroken' and 'anxious'. ${ }^{94}$ But irrespective of the heartache and hardships their relative's incarceration had caused, some families were unwilling to abandon them to Broadmoor.

III.

Families' anger, fear and sadness at how their lives had turned out and love and affection towards the relative who had caused those feelings were not mutually exclusive. This section examines families' words and actions, including visiting, to show how some united to support one another and to demonstrate their continued attachment to their relative.

Letter writing was an important means by which families communicated with relatives in asylums. In an effort to keep them part of the home, they shared exciting and mundane family news, sought advice, consoled relatives when they were ill or scared, admonished them if they misbehaved, and communicated their affection explicitly in their salutations. ${ }^{95}$ Family members placed emotional value on their letters, which could lessen the emotional if not physical distance between them. Upon hearing that his father was 'very depressed and restless in

\footnotetext{
${ }_{94}$ D/H14/D2/2/1/901/4-5; D/H14/D2/2/2/174/20; D/H14/D2/2/2/173/5; D/H14/D2/2/1/1102/58; D/H14/D2/2/1/791/6, all to superintendent. ${ }^{95} \mathrm{D} / \mathrm{H} 14 / \mathrm{D} 2 / 2 / 1 / 936 \mathrm{a} / 241$, to Dodwell; D/H14/D2/2/2/101/7, to Dyson; D/H14/D2/2/1/569/2, to Jones. Numerous family members referred to their 'Dear' relative. It was not merely a formality but, as David Fitzpatrick noted in his study of Irish and Australian migrant letters, was used to assure 'the reader that familial solidarity was in tact'. Oceans of consolation: personal accounts of Irish migration to Australia (Cork, 1994). p. 22.
} 
mind' Anthony Owston's son told the superintendent: 'I am writing to my father and trust that the letter may be handed to him as I think that a letter from home may be of great value to him at the present crisis.' ${ }^{96}$ He described another letter to his father as 'cheering'. ${ }^{97}$ Letters were not simply cheering platitudes, however, but sincere, intimate communication between and about relatives. Some family members sent their relative upbeat, comforting letters whilst simultaneously writing anxiety-ridden letters to the superintendent, suggesting a clear awareness of audience and the performativity involved in writing. One patient's mother begged the superintendent to 'take pity on her poor aged mother ... I cannot express my hartfelt grief ... relieve me of this distress and restore my daughter to me again or I will bring my gray hare and sorrow to the grave'. ${ }^{98}$ Although clearly feeling wretched, this mother still encouraged her daughter to 'keep your spirits up'. ${ }^{99}$ For some family members Broadmoor's superintendent became a confidant; ${ }^{100}$ they shared their troubles and some confessed they were keeping concerns or circumstances from their relatives, a situation akin to what David Gerber called an 'epistolary masquerade.'101 Given that they omitted bad news or worries or embellished the family's wellbeing to protect their relative, however, this should be read as an act of care and love. ${ }^{102}$ Letters to the superintendent highlight the existence of anxieties shared by family members around the world; they sought reassurance that relatives

\footnotetext{
$96 \mathrm{D} / \mathrm{H} 12 / \mathrm{D} 2 / 2 / 1 / 963 / 18$.

${ }^{97} \mathrm{D} / \mathrm{H} 14 / \mathrm{D} 2 / 2 / 1 / 963 / 31$.

$98 \mathrm{D} / \mathrm{H} 14 / \mathrm{D} 2 / 2 / 1 / 175 / 51$.

${ }^{99} \mathrm{D} / \mathrm{H} 14 / \mathrm{D} 2 / 2 / 2 / 175 / 11$.

100 This happened elsewhere. Wannell, 'Patients', pp. 307-8; Smith, 'Thankful', pp. 239-42.

101 David Gerber, 'Epistolary masquerades: acts of deceiving and withholding in immigrant letters', in Bruce Elliot, David Gerber and Suzanne Sinke, eds., Letters across borders: the epistolary practice of international migrants (London, 2006), pp. 144-57.

${ }^{102}$ As Michael Roper suggested of soldiers omitting danger in their letters to their mothers, The secret battle. Emotional survival in the Great War (Manchester, 2009), pp. 63-8.
} 
were eating, healthy and well treated, particularly if they had not heard from them. ${ }^{103}$ Families who received 'rational' and 'sane' letters from relatives struggled to understand or accept their medical diagnosis. ${ }^{104}$ Others asked about their relative's illness or chances of release. ${ }^{105}$ Requests for information suggest concern and attachment, as do requests for the superintendent's assistance. Some asked him to do something on their behalf, for instance compassionately delivering sad news to a relative. ${ }^{106}$ Others asked if they could send items photographs, musical instruments and clothing - to help their relative make a home for themselves. ${ }^{107}$ Regardless of how much they cared, family members' letters to the superintendent were 'supplications'; they sought action but 'recognised the discretionary power of the recipient.'108 Supplications to medical men contained an emotional performance, and it is fruitful to see them, like Coleborne, as a 'theatre of emotions'. ${ }^{109}$ The superintendent's power incentivized family member's expressions of their emotional and practical need for his assistance. Attentiveness to this dynamic reveals family member's attempts to exercise agency and that they understood their agency as circumscribed by the power of the superintendent. Such emotional performances also illustrate the strength of their familial attachment, explicitly in what was revealed to the superintendent, and implicitly, in the decision to communicate that they missed

\footnotetext{
103 D/H14/D2/2/1/1116; D/H14/D2/2/1/905/12; D/H14/D2/2/1/836/6. Wannell, 'Patients'; Coleborne, 'Families'. ${ }_{104}$ D/H14/D2/2/1/175/45, to superintendent. Also, D/H14/D2/2/1/1092/15; D/H14/D2/2/1/901/10. This happened elsewhere. Coleborne, Madness, p. 82; Walsh, 'Lunatic'. 105 As Oonagh Walsh found, 'Lunatic and criminal alliances in nineteenth-century Ireland', in Bartlett and Wright, eds., Outside, pp. 132-52 at p. 145. 106 D/H14/D2/2/2/178/7; D/H14/D2/2/2/212/16; D/H14/D2/2/1/975/13; D/H14/D1/2/1/936b/208; D/H14/D2/2/1/975/13. 107 D/H14/D2/2/1/918/3.

108 Andreas Wurgler, 'Voices from amongst the "Silent Masses": humble petitions and social conflicts in early modern central Europe' in L.-H. van Voss, ed., Petitions in social history (Cambridge, 2001), pp. 11-34, in King, Writing p. 49.

109 Coleborne, 'Families', p. 437.
} 
and cared for their relative without burdening them with their own heartache and difficulties.

Some families performed their attachment by visiting asylums, yet few historians have explicitly considered what this reveals about family life and emotions. Visiting institutions, as Jonathan Reinarz and Graham Mooney write, offered support to patients and 'provided an intimate link to a familiar world that is temporarily, or even permanently, out of reach.'110 Of course families visited Broadmoor to reassure relatives they had not been forgotten. Patient William Lloyd's father was desperate to know if his son remembered that his mother and brothers had visited him, and asked the superintendent to 'please let him know ... that some one else will come soon'.111 In a note suggesting families' actions were monitored, the superintendent told the Home Office that one patient's wife 'has all along been most kind and attentive to her husband in every way and she rented a house in this neighbourhood so that she should be able to come and see him frequently.'112 But visiting also benefitted families. Unlike at ordinary asylums where families might have encountered the asylum upon their relative's admission, the families of Broadmoor's patients might only have read about the asylum in the press, which sometimes printed sensational images of its 'Frankenstein'-like patients. ${ }^{113}$ Visiting may have relieved fears about who relatives' were living alongside, and enabled families to witness the kindness and respect (they hoped) relatives received. ${ }^{114}$ It also helped to ease emotional

\footnotetext{
110 Graham Mooney and Jonathan Reinarz, 'Hospital and asylum visiting in historical perspective: themes and issues', in Mooney and Reinarz, eds., Permeable walls: historical perspectives on hospital an asylum visiting (Amsterdam, 2009), pp. 7-30 at p. 9.

${ }^{111} \mathrm{D} / \mathrm{H} 14 / \mathrm{D} 2 / 2 / 1 / 761 / 5$.

$112 \mathrm{D} / \mathrm{H} 14 / \mathrm{D} 2 / 2 / 1 / 1254 / 56$.

113 'A visit to the Criminal Lunatic Asylum', The Times, 13 Jan. 1865, p. 10.

${ }^{114}$ Some relatives expressed relief that they had encountered their relative in a good condition.
} 
distress by temporarily reuniting families.

As elsewhere though, many found the prospect and the act of visiting emotionally testing. They might have (or have feared) a distressing encounter with a relative whom they found in a worse condition than expected, or receive abuse from a previously loving relative. ${ }^{115}$ The asylum's visitor's room sometimes became a site of domestic tension. Dodwell's daughter left the visitor's room 'in tears' after he scolded her for questioning him. ${ }^{116}$ One patient entered the visitor's room and 'embraced the children, but he motioned with his hand for his wife to keep back' and told her, 'you beast keep back, or I will floor you'. She told the supervising attendant, 'I will go it only irritates him my being here'.117 That some family members visited despite the practical and emotional challenges it posed indicates the strength of their attachment and the significance they placed upon the act. The devotion of one patient's husband is evidenced by his visits. The superintendent recorded, 'when her husband visited her, and spent the portions of three days with her, she refused to speak to him.'118 Despite his wife's silence, he returned to sit with her every day for three days. We cannot know why he returned, but unlike other relatives who asked the superintendent whether visiting was worthwhile (would the patient recognize them? would they speak to them?), this husband appears unconcerned with such matters. Of course, he might have hoped his wife would talk to him, but when

\footnotetext{
115 Frederick Crawley's sister 'was grieved to find him so low and ill', D/H14/D2/2/1/698/7, to superintendent; D/H14/D2/2/1/761/5; Catharine Coleborne, 'Challenging institutional hegemony: family visitors to hospitals for the insane in Australia and New Zealand, 1880s1890s', in Mooney and Reinarz, eds., Permeable, pp. 289-308 at p. 301; Geoffrey Reaume, Remembrance of patients past: patient life at Toronto hospital for the insane, 1870-1940 (Oxford, 2000, p. 189.

$116 \mathrm{D} / \mathrm{H} 14 / \mathrm{D} 2 / 2 / 1 / 936 \mathrm{c} / 51$, attendant's note. 117 D/H14/D2/2/1/1256/14, attendant's note. 118 William Orange, Reports of the superintendent and chaplain of Broadmoor Criminal Lunatic Asylum for the year 1875 (London, 1876), p. 44.
} 
faced with the possibility that each day would be the same, he would seemingly rather sit with her in silence than not at all. We do not have access to his conversations with the superintendent or medical officers, we do not know what words, if any, he spoke to his wife. There is no explicit record of emotion in this case; there are no references to sadness, anger or fear, as in some other accounts. This does not mean the husband did not feel them of course, and if other family members' accounts of visiting are considered it is possible that rather than taking solace from being in his wife's presence he found his visits heartbreaking.

Some patients' case files contain visitor's slips detailing who visited and when. They do not all have them, and it might be assumed that patients' received no visitors and were, as some patients' complained and feared, and as some historians have deduced, 'abandoned' by their families. ${ }^{119}$ Certainly not all families were willing to visit a relative whose crime and asylum committal had caused them misery, ${ }^{120}$ but the existence of few, no or a dwindling number of visitors' slips is not necessarily evidence of desertion. Not only might some have been lost in the record-keeping process, but examining correspondence to the superintendent reveals various reasons why families could not or would not visit, significantly adding to our understandings of the reach and impact of the asylum whilst simultaneously highlighting affective familial relationships. There are the expected practical reasons; it required money and time, both of which many families lacked, to make the (often long) journey to Broadmoor. ${ }^{121}$ Joseph Redding's wife could not visit for 'two reasons. I have not had the means as I was

119 D/H14/D2/2/1/936b/57, to attendant; D/H14/D2/2/1/936c/10, from Dodwell to son. Reaume, Remembrance, p. 196.

${ }^{120}$ D/H14/D2/2/1/1310, medical report.

${ }^{121}$ Letters to superintendent in D/H14/D2/2/1/969/8; D/H14/D2/2/1/1230/2;

D/H14/D2/2/1/918/9. 
left with six children and myself to provide for. I have also been suffering with change of life. There as been many obsticles in my way which I have not wanted to trouble him with.' ${ }^{\prime 22}$ The need to hide troubles formed part of Redding's justification; similar to omissions in letters, not visiting was framed as an act of care. Practical barriers could be insurmountable, but emotional barriers could be too. Some family members tried to pre-empt (and avoid) emotionally difficult visits. Many worried that their relative had lost their sense of self, and the potential heartbreak of encountering someone they did not recognize deterred some from visiting. ${ }^{123}$ Others resisted visiting because they dreaded saying goodbye. Following his father's death one man told the superintendent: Thanking you very much for letting me know. I feel it very much indeed as we have been thinking of coming to see him all the winter ... but it seems we are too late and I feel now I can't see him alive it is no use to see him buried ... I only wish I had come before but I dreaded the parting so much. ${ }^{124}$

It was not always the visit itself that families disliked, but the near inevitability of travelling home, alone, at the end of the day. ${ }^{125}$

IV.

Some family members petitioned for their relative's release, seeking to reduce the material and emotional burdens writing to or visiting Broadmoor (or the inability to do so) had caused. But doing so and the realities of family life post-

\footnotetext{
$122 \mathrm{D} / \mathrm{H} 14 / \mathrm{D} 2 / 2 / 1 / 1102 / 70$.

${ }^{123} \mathrm{D} / \mathrm{H} 14 / \mathrm{D} 2 / 2 / 2 / 183 / 9$, to superintendent.

${ }^{124} \mathrm{D} / \mathrm{H} 14 / \mathrm{D} 2 / 2 / 1 / 659 / 9$.

$125 \mathrm{D} / \mathrm{H} 14 / \mathrm{D} 2 / 2 / 1 / 1705$.
} 
discharge sometimes caused further heartache, and further curtailed families' agency.

Applying for release was a bureaucratic, time-consuming process.

Patients' families petitioned the Home Office, which requested a medical report and the superintendent's opinion. This exposed the family to scrutiny and judgment, and it was usually unsuccessful. That many families did it anyway, sometimes often and over many years, suggests the strength of their attachment. ${ }^{126}$ Correspondence reveals various reasons why families wanted a relative home. Looking at other asylums, historians have argued that economic concerns drove families' petitions, but this misrepresents the complexity of families' lives and feelings. ${ }^{127}$ While poverty motivated some petitions to Broadmoor, economic concerns were not always the driving or only factor. Families wanted relatives home because they loved and missed them and 'did not like' the thought of them dying at Broadmoor; moreover they offered to financially support their relative upon release. ${ }^{128}$ Additionally, these motivations are not mutually exclusive and strong emotional attachments persisted despite financial hardship.

Successful petitions usually resulted in a conditional discharge, which legally obligated the petitioning family member to care for their relative and to report changes in their mental and physical condition to the Home Office and to Broadmoor indefinitely. Even if patients exhibited 'sane' traits, including the

\footnotetext{
126 Not all families had room for a wage earner, carer, or parent whose role in the home was rendered void by their committal into Broadmoor, and some refused to care for them should they be released. Space constraints prevent this being unpacked here.

127 Smith, 'Living'; Smith, 'Thankful', pp. 246-8. Families of the Irish insane highlighted their financial burdens. Mauger, Cost, pp. 74 and 100.

${ }^{128}$ For example cases: D/H14/D2/2/1/ 976/39; D/H14/D2/2/1/1085; D/H14/D2/2/1/974/3;

D/H14/D2/2/1/366; D/H14/D2/2/1/1076; D/H14/D2/2/1/186; D/H14/D2/2/1/999/15.
} 
ability to work and self-control, their discharge could be refused, ${ }^{129}$ because the superintendent was unconvinced about the petitioning family member's character or ability to care for and supervise their relative. Applications were thus a stage upon which family members performed their emotions and their lives. Clearly aware of the expectations placed upon them, some described their homes, supportive family networks, their employment and relative financial stability. ${ }^{130}$ Just as patients' might have performed their recoveries in an effort to secure release, and as Coleborne notes, family members might also have performed to help secure the release of a relative they needed at home.131

Petitions emphasized familial bonds, particularly the (alleged) willingness of female family members, especially sisters and sisters-in-law, to care for discharged relatives. ${ }^{132}$ Women, seen as the moral cornerstone of familial life, ${ }^{133}$ typically bore the responsibility for familial care in Victorian society, ${ }^{134}$ with sisters expected to assume a parental role if required. ${ }^{135}$ When trying to secure the release of his brother-in-law, John Mellor emphasized the strength of sibling bonds to the superintendent:

my good wife his sister being like a mother to him ... has a power of control over him that makes me have no doubt ... if he is released and sent

\footnotetext{
129 Shepherd, 'Very glad', p. 476.

${ }^{130} \mathrm{D} / \mathrm{H} 14 / \mathrm{D} 2 / 2 / 1 / 1102 / 58$, to superintendent; D/H14/D2/2/1/714/7, to superintendent.

131 Coleborne, 'Families', p. 438.

132 D/H14/D2/2/1/186/26, to superintendent.

133 Léonore Davidoff, Thicker than water: siblings and their relations, 1780-1920 (Oxford, 2012), p. 131.

134 David Wright, 'Familial care of "idiot" children in Victorian England', in Hordon and Smith, eds., The locus of care: families, communities, institutions, and the provision of welfare since antiquity (London, 1998), pp. 176-97 at pp. 182-3.

135 Nelson, Family, pp. 110-11; Frost, Victorian, p. 18.
} 
here he will be safe and cared for in a manner that will enable him to become a useful member of society. ${ }^{136}$

Other families offered to make space for and care for their relative in their often already over-crowded homes. ${ }^{137}$ It is telling that some families were willing and able to open their homes to a relative whose crime and committal had caused them suffering, but some were even prepared to welcome unrelated criminal lunatics. One former patient's husband, perhaps recognising that it would increase the happiness of his discharged wife, offered a home and financial support to a patient she had befriended in Broadmoor and held 'a sisterly regard' towards. ${ }^{138}$ Such evidence further challenges the assumption that families only sought the release of relatives who could contribute to the running of the household, and highlights the strength of emotional bonds.

Strong familial bonds alone would not persuade the superintendent to recommend discharge. Unlike at other asylums, Broadmoor's patients' families could not simply demand their release and expect a positive outcome. ${ }^{139}$ Petitions were denied because families' homes or incomes were deemed unable to accommodate or support another member, ${ }^{140}$ because family members drank or were unemployed, or because the superintendent doubted they could supervise and control the patient if they relapsed. ${ }^{141}$ Those with low levels of agency - women, the elderly and the poor - not only felt the effect of a relative's incarceration most keenly but were also less likely to be deemed able guardians.

\footnotetext{
136 D/H14/D2/2/1/1284/28. Also, D/H14/D2//2/1/714/7.

137 For example, D/H14/D2/2/1/ 976/39; D/H14/D2/2/1/1085; D/H14/D2/2/1/974/3;

D/H14/D2/2/1/366; D/H14/D2/2/1/1076; D/H14/D2/2/1/186; D/H14/D2/2/1/999/15.

138 D/H14/D2/2/2/107/5-6

139 Wright, 'Discharge', p. 98.

${ }^{140} \mathrm{D} / \mathrm{H} 14 / \mathrm{D} 2 / 2 / 1 / 1738$, from police constable to superintendent.

${ }^{141}$ D/H14/D2/2/1/388/11; William Orange, Reports of the Superintendent and Chaplain of Broadmoor Criminal Lunatic Asylum for the Year 1885 (London, 1886), p. 6.
} 
For some, a relative's return home was and remained (as far as the records suggest) a joyous occasion. As at other asylums, former patients and their families wrote to Broadmoor's superintendent describing their delight, relief and gratitude, and detailing their successful transition back into society. ${ }^{142}$ Some reunions did not quell the anguish, fear, sadness and grief some family members felt during their relative's institutionalization, even if it was something they had longed for. Some found it difficult to care for and supervise their relative, particularly alongside working, maintaining a household, or parenting. If relatives were amenable post-release, and if families had some financial independence, minor difficulties, including loss of space within the home, could be managed. Five months after his sister's release one man informed the superintendent that she was no longer 'residing with us'. He and other relatives had 'furnished her a nice little home at her own choice ... as it is more convenient for us.' ${ }^{143}$ But some families were unable to cope, particularly if their relative became violent or intemperate. ${ }^{144}$ In such cases family members had little choice but to inform the superintendent, knowing their relative would be recommitted. Such cases, can though, indicate strong emotional bonds. Despite the havoc their relative's relapse into intemperance wrought upon their homes, Mary Ann Mellor's husband - whose wife had pawned their belongings - and Matthew Cook's sister - who had lent Cook money he could not repay - both waited four months before informing the superintendent, hoping they would recover at

\footnotetext{
142 For example the following letters to superintendent, D/H14/D2/2/1/905/33;

D/H14/D2/2/366/177; D/H14/D2/2/1/975/2; D/H14/D2/2/2/107/5;

D/H14/D2/2/2/100/25; D/H14/D2/2/2/398/41; D/H14/D2/2/2/164/19-20. Smith,

'Thankful', p. 248.

143 D/H14/D2/2/2174/35.

${ }^{144}$ Lucy Thompson's brother requested her committal after she attacked him and his wife, D/H14/D2/2/2/105. Similarly, D/H14/D2/2/1/1705.
} 
home. ${ }^{145}$ Even then Cook's sister wrote to the superintendent with 'heartfelt sorrow'. ${ }^{146}$ Unlike at ordinary asylums families played no role in their relative's initial admission into Broadmoor, but like at ordinary asylums some families decided to (re)commit only after a prolonged period of distress, when they could no longer manage their relative at home. ${ }^{147}$ This suggests, as Steven Taylor notes in his study of child insanity, that families had 'strong emotional bonds' with their ill relatives 'and were eager to preserve these.'148

Examining petitioning, discharge and post-asylum life, demonstrates the extent to which persistent observation rendered families both victims and quasipatients of a system designed to confine, control and rehabilitate criminal lunatics. Foucauldian approaches to the history of psychiatry position asylums as instruments of social control, focusing on the surveillance and re-modelling of patients into ideal (bourgeois) members of society. ${ }^{149}$ Scholars have highlighted the 'long history of surveillance' outside of the institution, and that families policed, watched and controlled insane relatives within the home, sometimes before their asylum committal. ${ }^{150}$ This policing was supplemented and encouraged by doctors entering the domestic sphere, and by neighbours whose curiosity and gossiping led some families to hide their ill relative. ${ }^{151}$ The role of English county asylums (and thus the State) in policing patients' families during

\footnotetext{
${ }_{145} \mathrm{D} / \mathrm{H} 14 / \mathrm{D} 2 / 2 / 2 / 146 / 6-7 ; \mathrm{D} / \mathrm{H} 14 / \mathrm{D} 2 / 2 / 1 / 1013$.

${ }_{146} \mathrm{D} / \mathrm{H} 14 / \mathrm{D} 2 / 2 / 1 / 1013$.

147 Historians agree that families' viewed asylums as a last resort. For example, Hilary Marland, 'At home with puerperal mania: the domestic treatment of the insanity of childbirth in the nineteenth century', in Bartlett and Wright, eds., Outside, pp. 45-65; Suzuki, Madness; Wright, 'Discharge'.

${ }^{148}$ Steven Taylor, "She was frightened while pregnant by a monkey at the zoo": constructing the mentally-imperfect child in nineteenth-century England', Social History of Medicine, 30 (2017), pp. 748-766 at p. 765 .

149 Foucault, History, p. 485.

${ }^{150}$ Peter Bartlett and David Wright, 'Community care and its antecedents', in Bartlett and Wright, eds., Outside, pp. 1-8, 13.

151 Marland, 'At home'; Suzuki, Madness.
} 
and after their relative's asylum stay is rarely examined. Broadmoor extended the surveillance typically associated with inside institutions to the family and the family home both before and after patients' discharge. Families' actions and health were observed to determine whether their relative should be discharged. If they were, the price of release was accepting the roles of actor and subject in continued surveillance. Families had to police and report their relative's behaviour, or the police would enquire. ${ }^{152}$ The Discharged Prisoner's Aid Society watched some former patients and their families and reported their behaviour to Broadmoor. ${ }^{153}$ Former patients watched their family members, too; some reported their misdeeds to the superintendent, particularly if they wanted to move out of their home. ${ }^{154}$ Families' agency was thus limited by their relative's committal and further curtailed by their release. Families' remained supervised and in limbo as long as their relative lived, and for as long as they remained committed to them even if they were eventually discharged; this was not lost on some of their friends: 'I can't help but wishing that the poor fellow may die, for it seems such a wretched life for the poor little woman to go on hoping against hope.'155 For family members who wished to remain in contact with their relative, any semblance of agency would only return upon their relative's death.

V.

The extension of the family and familial support into Broadmoor lasted over the course of some patients' lives. When their relatives were dying, some families

\footnotetext{
$152 \mathrm{D} / \mathrm{H} 14 / \mathrm{D} 2 / 2 / 1 / 1705$.

${ }^{153} \mathrm{D} / \mathrm{H} 14 / \mathrm{D} 2 / 2 / 2 / 105$.

${ }^{154} \mathrm{D} / \mathrm{H} 14 / \mathrm{D} 2 / 2 / 2 / 105 / 16$. D/H14/D2/2/1/1565

155 D/H14/D2/2/1/918/7, to superintendent.
} 
were shocked and saddened, especially if they were unable to visit the asylum. ${ }^{156}$ Some appeared fearful, particularly if they had strong religious faith. Perhaps in an effort to support them on their final journey, such family members beseeched their relatives to atone before it was too late. ${ }^{157}$ As well as relying on tangible support networks, some found solace in the prospect of an afterlife. One dying patient's brother asked the superintendent:

to convey to my brother my ever best and most affectionate love to him for his true happiness in this world to come to be happy for ever \& ever through our Lord and Saviour Jesus Christ this is my ever earnest prayer to the Lord Jesus on his behalf that if I do not see him any more in this world, that I do hope to meet him in heaven, where parting will be no more. ${ }^{158}$

Families' letters to Broadmoor during and after their relative's final illness suggest strong familial bonds. The bereaved sometimes expressed sorrow and regret, particularly if they had been unable to visit their relative whilst they were alive, and especially if they had been absent at their death. ${ }^{159}$ In Victorian society witnessing a relative's death provided a sense of control and (it was hoped) the comfort of knowing their final hours were painless. ${ }^{160}$ Family members unable to be at their dying relative's side, or those informed of a sudden death, sought comfort; they asked the superintendent about their final

\footnotetext{
156 Family members were invited to visit and stay with their dying relative. Rules for the guidance of the officers of Broadmoor Criminal Lunatic Asylum (London, 1863).

157 D/H14/D2/2/1/973/5, to Thornley.

$158 \mathrm{D} / \mathrm{H} 14 / \mathrm{D} 2 / 2 / 1 / 605 / 5$.

${ }_{159} \mathrm{D} / \mathrm{H} 14 / \mathrm{D} 2 / 2 / 1 / 739 / 11$, to superintendent.

160 Strange, Death, p. 50 .
} 
days, presumably seeking reassurance they were not alone or in pain. ${ }^{161}$ Some family members might have been indifferent to a relative's death, particularly if their relationship had been fraught, yet even when relationships had been fractious sorrow still materialized. When Dodwell died in 1900 he had not seen his daughters or seen or heard from his previously dutiful son Edward for many years. Until his death Dodwell's relationship with his family seemed irreparable, yet his son Henry's final letter to the superintendent described his love and sorrow, and declared, 'I shall ever deeply regret my absence from his side at the last.'162 Perhaps trying to console Henry, the superintendent replied that he was the only person Dodwell had wished to see before his death but he had not known where a telegram might reach him in time. ${ }^{163}$ Many bereaved family members, including Henry, also expressed relief; the end of relatives' 'pain and sorrow' was a 'great blessing'. ${ }^{164}$ Given the emotional and financial burdens patients' families carried, a relative's death released all involved. Families no longer had to worry about visiting or writing, or about their relative's health or treatment, and they were no longer policed. It might also have eased any familial tension outside of Broadmoor.

Most patients who died at Broadmoor were buried there because it cost families nothing. Some regretted this. Isobel Taylor told the superintendent: 'I should [have] liked [my aunt] to have been buried at Armitage Bridge Church, but I find it will be expensive and I have my aged father to live [with] me having

\footnotetext{
${ }_{161} \mathrm{D} / \mathrm{H} 14 / \mathrm{D} 2 / 2 / 2 / 183 / 67 ; \mathrm{D} / \mathrm{H} 14 / \mathrm{D} 2 / 2 / 1 / 743 / 6 ; \mathrm{D} / \mathrm{H} 14 / \mathrm{D} 2 / 2 / 1 / 743$;

$\mathrm{D} / \mathrm{H} 14 / \mathrm{D} 2 / 2 / 1 / 964 / 15$.

162 D/H14/D2/2/1/936c/216.

$163 \mathrm{D} / \mathrm{H} 14 / \mathrm{D} 2 / 2 / 1 / 936 \mathrm{c} / 217$.

${ }_{164}$ D/H14/D2/2/2/178/36; D/H14/D2/2/1/973/9; D/H14/D2/2/1/1075/14;

D/H14/D2/2/1/569/12; D/H14/D2/2/2/178/36; D/H14/D2/2/2/1075/14;

D/H14/D2/2/2/183/67, all to superintendent.
} 
only lately lost my mother. ${ }^{165}$ Like other Victorian women, Taylor had assumed the duty of caring for her elderly father; the cost of fulfilling her filial duty prevented her doing as she wished for her aunt. Many family members, including Taylor, also regretted their inability to attend their relative's funeral; the cost and distance remained too great. ${ }^{166}$ While usual Victorian burial sites 'represented a locus for expressions of grief and commemoration through the installation of headstones, gifts of flowers, and visits to the grave',167 Broadmoor's was comparatively austere. But empty, unadorned gravesides represented not a life unloved or forgotten, but the hardships and insurmountable responsibilities faced by the working families of the Victorian criminally insane. Although Broadmoor's burial space undoubtedly received fewer mourners than a typical Victorian cemetery, some family members were able to visit to grieve and remember. ${ }^{168}$ Following a relative's funeral some families continued to demonstrate their love. Anthony Owston's sons sent wreaths to be placed upon his grave each Christmas, Easter and on the anniversary of his death, prolonging their emotional connection with the asylum where their father had spent the majority of their lives. ${ }^{169}$

Some families rejected a private burial because they believed that after years of incarceration Broadmoor was their relative's rightful resting place. ${ }^{170}$ Others seized the opportunity to arrange a funeral away from Broadmoor. George Thomas Pett was, his wife told the superintendent, 'laid to rest where I

${ }^{165} \mathrm{D} / \mathrm{H} 14 / \mathrm{D} 2 / 2 / 2 / 2 / 183 / 67$.

${ }_{166}$ D/H14/D2/2/1/400; D/H14/D2/2/2/166/10; D/H14/D2/2/1/740/28;

D/H14/D2/2/1/996/29-30; D/H14/D2/2/1/659/12; D/H14/D2/2/1/964/15; D/H14/D2/2/1/996/29-30; D/H14/D2/2/1/760/38, 23; D/H14/D2/2/2/178/30. 167 Strange, Death, p. 192.

168 Some family members thanked the superintendent for the service. D/H14/D2/2/1/918/2223. 
know he longed to be with our little girl Lillian.'171 Dodwell was buried in Woking Cemetery, 'far from that place that has so cruelly held him for over 22 long years from those that loved him so dearly.'172 After years of trying and failing to liberate their loved one, exercising the power to remove their body from Broadmoor was one way families demonstrated their love and attachment. It also meant that they could finally fulfill their (often years' old) promise, without the agreement of the Home Office and the asylum's superintendent, to bring their relative home.

VI.

The Broadmoor archive is a repository of love, sorrow, and hope, alive with stories of loss, poverty, desperation and kinship. Analysis of families' correspondence to the asylum has enabled the first in-depth examination of the effects of asylum committal on individual family members. The findings demonstrate the value of considering the lives, experiences and subjective identities of individual family members, focusing on their words and actions and sometimes their silence - and paying close attention to factors including class, life stage (and age) and, in cases of long-term committal, change over time. This article demonstrates that asylums affected patients' families in more varied and complex ways than has previously been acknowledged. We see the financial and emotional distress caused, especially to wives, how individual identities were challenged and reconfigured, and the curtailment of individuals' (often already limited) agency, not least because the asylum observed them, too. But

\footnotetext{
${ }^{171} \mathrm{D} / \mathrm{H} 14 / \mathrm{D} 2 / 2 / 1 / 1689$.

172 D/H14/D2/2/1/936c/216, to superintendent.
} 
kinship also proved resilient; despite these difficulties family members strove to maintain relationships with, and to care for, their relative during and after their incarceration. Crucially, we see their motivations were not limited to, or even primarily, financial, but were shaped by a desire to preserve familial bonds, even if in circumscribed form. Evidently, some families tried and managed to give meaning to relationships altered by the asylum. The Broadmoor correspondence demonstrates families' presence within the asylum but also highlights the need for more nuanced readings of their absence: it did not necessarily mean abandonment, but poverty, love, fear and sadness.

The significance and resilience of affective family bonds for patients' family members found here shows that to fully understand how the impacts of committal reverberated beyond the asylum's walls we must re-evaluate other collections of correspondence with a closer engagement with the history of the family. Doing so will allow existing assumptions about the (most significant) effects on families to be reviewed, and will further illuminate the effects of asylum committal on conceptions of the self and the family. Although outside the scope of this article, comparing how families in different regions appeared to cope with losing a relative to the asylum may reveal the role regional social and cultural differences, and localized understandings of kinship, played in families' ability to withstand the committal of a relative, and shed further light on the history of the family. Historians must continue to look beyond the asylum's walls. Only when we understand the broader social impacts of (long-term, longdistance) asylum committal will we start to understand the full extent of the role and significance of the Victorian asylum. 